\title{
Risk assessment of Typhoons and storm surges disasters of Qinhuangdao
}

\author{
Suli Sun ${ }^{1}$ Wanlei Zhang ${ }^{2} \quad$ Zhizheng Mao ${ }^{1}$ Chenyu Zhang \\ 1 Meteorological Bureau of Qinhuangdao,Hebei 2Marine Forecasting Center of Hebei \\ Qinhuangdao, China \\ sunsuli@sina.com \\ 秦皇向台风心风暴潮灾害风(险平估 \\ 孙素丽 $^{1}$ 张万磊 $^{2}$ 毛智政 ${ }^{1}$ 张晨宇 $^{1}$ \\ 1 河北省秦皇岛市气象局 2 河北省海洋预报台 \\ 秦皇岛 邮编 066000 中国 \\ sunsuli@sina.com
}

Abstract-Through the statistical analysis of meteorological and oceanographic data of Qinhuangdao in the past 70 years, we found that there is about one typhoon landing in Qinhuangdao in about every 2-3 years, which induces heavy rain, strong wind and even storm surge. Typhoons that landed in the Bohai Bay in the past decade have increased significantly. In particular, there were three typhoons landing in 2018, and the disasters caused by the growth of the landing typhoons show an increasing trend. According to the comprehensive strength formula of typhoon and wind and rain assessment, the typhoon is divided into three levels: the first type is strong typhoons: causing strong winds or heavy storm surges, which can cause serious natural disasters, such as falling crops, flooding, collapsed buildings and facilities, casualties, distressed sea vessels, and flooded coastal zones. The second type is relative strong typhoons: accompanied with large precipitation (50-100mm), strong winds (maximum wind speed of $10-10 \mathrm{~m} / \mathrm{s}$ in 10 minutes, maximum wind speed between $13.6-17 \mathrm{~m} / \mathrm{s}$ ), or water exceeding warning level with high tide but without strong winds. It may cause serious disasters, but it is as serious as the first type. The third type is weak typhoons with no disaster. Qinhuangdao is located at north side of the Bohai Sea and its coastline is in the northeast-southwest direction. In addition to the typhoons, the weather system that causes the storm surge in Qinhuangdao also includes the strong extratropical cyclones which are accompanied with large southeast wind component (generally the maximum wind speed of 10 minutes is greater than $10 \mathrm{~m} / \mathrm{s}$, the maximum wind speed is greater than $17 \mathrm{~m} / \mathrm{s}$ ), winds in the northwest direction will lead the water away from the coast. If this wind effect is compound with the astronomical tide, it can cause storm surges.
Keywords-Typhoon storm surgedisaster

摘要一通过对秦皇岛近 70 年台风、风暴潮的气象、海洋资 料进行统计分析, 结果显示: 秦皇岛大约 2-3 年会受到一个台 风影响, 造成暴雨、大风甚至风暴潮。近十年登陆渤海湾的台 风明显增加, 造成的灾害也呈增长趋势, 尤其是 2018 年共有 3 个台风影响。根据台风风雨评估综合强度公式将台风分为三 个等级：第一类强影响台风: 造成大风强降水或大的风暴潮, 可以造成严重的自然灾害; 第二类较强影响台风: 较大降水 (50-100mm), 较强大风 (十分钟最大风速在 8-10m/s 之间, 极大风速在 $13.6-17 \mathrm{~m} / \mathrm{s}$ 之间), 或超过警戒水位但没有大风的 高潮位, 可能会造成比较严重的灾害; 第三类弱影响台风: 无 灾情。造成秦皇岛风暴潮的天气系统除了台风还有强的温带气 旋和强冷空气。秦皇岛海岸线成东北-西南向, 只有带有东南 分量的大风才能产生风暴增水（一般十分钟最大风速大于 $10 \mathrm{~m} / \mathrm{s}$, 极大风速大于 $17 \mathrm{~m} / \mathrm{s}$ ), 西北方向分量的大风反而会 产生风暴减水。如果预报准确, 防范及时, 可能减少人员伤亡 和财产损失。

关键词一台风风暴潮灾害

\section{I . 引言}

台风是产生于热带地区海面的低压系统。一年影响 我国的台风有十几个, 但北上进入渤海湾的台风却很少, 平均两三年一个, 一般强度已减弱。近十年北上台风有 增加趋势。风暴潮是由于剧烈的大气扰动, 如强风和气 压骤变 (通常指台风和温带气旋等灾害性天气系统) 导致 海水异常升降, 同时和天文潮 (通常指潮汐) 叠加时的情 况, 如果这种叠加恰好是强烈的低气压风暴涌浪形成的 高涌浪与天文高潮叠加则会形成更强的破坏力。秦皇岛 地处渤海北岸, 海岸线呈东北西南向, 西起㴒河口, 与 唐山接壤，东至山海关造船厂，与辽宁相邻。沿岸东部 
有山海关造船厂、秦皇岛港、北戴河旅游区, 黄金海岸, 西部还有很多养殖场, 货场, 农作物等。受台风、风暴 潮影响沿岸设施损毁, 海水倒灌, 还可能造成农作物、 房屋被淹，甚至人员伤亡。

王月宾对影响渤海西岸的台风、风暴潮做过深入的 研究, 并总结了 1950 年以来进入渤海湾的台风路径、特 点、造成的灾害等。进入渤海湾的台风一般在 7 月下旬 到 9 月上旬, 最早也有 6 月份进入渤海湾的。章国材对 台风的风险评估进行了总结, 指出: 台风致灾因子主要 是风雨潮。王秀荣对台风灾害建立了评估模型。秦皇岛 对台风风暴潮的系统性研究还很少, 有必要对其进行统 计、研究、评估。

\section{II. 资料的选取}

资料选取 1949 到 2018 年近 70 年进入渤海湾共 28 个台风的路径、强度、时间等, 资料来源于中国台风网。 秦皇岛本地大风降雨量资料来源于秦皇岛五个国家站气 象地面观测资料。风暴潮灾情及潮位资料来源于河北省 海洋预报台, 见表 1 。由于秦皇岛只有 1954 年以后的气 象观测资料，所以只有 1954 年以后的降水资料、1970 年以后的日十分钟最大大风资料、2004 年以后的极大风 速资料。只有 2008-2018 年的超警戒水位（200 厘米） 的高潮潮位资料。1949-2007 年只有灾情严重的风暴潮 灾情和高潮位记录。

表 1 进入渤海湾台风个例

\begin{tabular}{|c|c|c|c|c|c|c|c|c|c|c|}
\hline 日期 & 农历 & 编号 & $\begin{array}{l}20-20 \text { 时 } \\
\text { 降水量 }\end{array}$ & $\begin{array}{l}\text { 日最大 } \\
\text { 风速 }\end{array}$ & $\begin{array}{l}\text { 日最大 } \\
\text { 风向 }\end{array}$ & $\begin{array}{l}\text { 日极大 } \\
\text { 风速 }\end{array}$ & $\begin{array}{l}\text { 日极大 } \\
\text { 风向 }\end{array}$ & $\begin{array}{l}\text { 中心 } \\
\text { 气压 } \\
\mathrm{hPa}\end{array}$ & $\begin{array}{l}\text { 中心最大 } \\
\text { 风速 } \\
(\mathrm{m} / \mathrm{s})\end{array}$ & $\begin{array}{l}\text { 风雨 } \\
\text { 综合 } \\
\text { 指数 }\end{array}$ \\
\hline 1950.8 .2 & 6.19 & 5010 & & & & & & 998 & 9 & \\
\hline 1953. 8. 21 & 7.12 & 5310 & & & & & & 1004 & 12 & \\
\hline 1960.7.28 & 6.5 & 6005 & 30.2 & & & & & 997 & 20 & \\
\hline 1960.8 .5 & 6.13 & 6007 & 14.7 & & & & & 1003 & 9 & \\
\hline 1963.7 .2 & 5.3 & 6306 & 168 & & & & & 998 & 20 & $>2$ \\
\hline 1967.7.29 & 6.21 & 6705 & 23.9 & & & & & 995 & 20 & \\
\hline 1972.7.27 & 6.16 & 7203 & 61.3 & 21.3 & ENE & & & 975 & 25 & 3 \\
\hline 1973. 7.19 & 6.20 & 7303 & 16.6 & 7 & $\mathrm{NE}$ & & & 985 & 12 & 0 \\
\hline 1974. 8. 30 & 7.13 & 7416 & 23.4 & 10.3 & $\mathrm{~N}$ & & & 986 & 25 & 0.4 \\
\hline 1978. 7. 26 & 6.21 & 7805 & 150.2 & 11.7 & ESE & & & 1001 & 9 & 2.4 \\
\hline 1981.7.27 & 6.26 & 8108 & 46.3 & 4.3 & SSW & & & 986 & 25 & 0.3 \\
\hline 1984. 8. 4 & 7.6 & 8406 & 51.6 & 5 & SSW & & & 1000 & 12 & 0.4 \\
\hline 1985. 8. 19 & 7.4 & 8509 & 69.2 & 11 & NNE & & & 981 & 30 & 1.1 \\
\hline 1992.9. 1 & 8.5 & 9216 & 18 & 9.7 & $\mathrm{NE}$ & & & 990 & 12 & 0.3 \\
\hline 1997. 8. 20 & 7.18 & 9711 & 64.9 & 14 & ENE & & & 990 & 20 & 1.6 \\
\hline 2001. 8. 2 & 6.12 & 0108 & 39.7 & 12.7 & $\mathrm{~N}$ & & & 1004 & 12 & 1.4 \\
\hline 2002.7.28 & 6.19 & 0209 & 103.4 & 6.3 & E & & & 1006 & 10 & 1.0 \\
\hline 2004.9.15 & 8.2 & 0421 & 73.6 & 12 & ESE & 17 & ENE & 1000 & 15 & 1.7 \\
\hline 2005. 8.8 & 7.4 & 0509 & 37.6 & 8 & $\mathrm{NE}$ & 14.8 & $\mathrm{NE}$ & 995 & 15 & 0.4 \\
\hline 2008. 7. 30 & & 0808 & 14 & 4. 9 & SE & 7.9 & SSE & & & 0 \\
\hline 7.31 & 6.29 & & & & & & & 1002 & 10 & \\
\hline 2011. 6.26 & 5.25 & 1105 & 0.2 & 8.2 & $\mathrm{NE}$ & 11.8 & ENE & 985 & 23 & 0 \\
\hline 2011. 8. 7 & & 1109 & 8.4 & 4.6 & $\mathrm{E}$ & 6.7 & $\mathrm{E}$ & & & \\
\hline 8.8 & 7.9 & & & & & & & 980 & 25 & \\
\hline 2012.8. 3 & 6.16 & 1210 & 51.2 & 7.4 & ENE & 10.6 & $\mathrm{E}$ & 1000 & 13 & \\
\hline 8.4 & 6.17 & 1210 & 183.8 & 11.6 & $\mathrm{NE}$ & 17 & $\mathrm{NE}$ & & & 2.6 \\
\hline 2012. 8. 28 & 7. 12 & 1215 & 0 & 3.7 & WNW & 5.4 & WNW & 975 & 28 & 0 \\
\hline 2017.8. 3 & 6.12 & 1710 & 162.3 & 9.8 & ENE & 17.9 & SE & 995 & 16 & 2.9 \\
\hline 2018. 7. 24 & 6.12 & 1810 & 127.7 & 12.5 & S & 21.5 & SE & 990 & 18 & 2.8 \\
\hline 2018. 8. 14 & 7.4 & 1814 & 177.9 & 11.9 & $\mathrm{NE}$ & 19.3 & $\mathrm{NE}$ & 997 & 16 & 3.0 \\
\hline 2018. 8. 20 & 7.10 & 1818 & 38.3 & 8.3 & $\mathrm{NE}$ & 14.8 & $\mathrm{NE}$ & 995 & 18 & 0.4 \\
\hline
\end{tabular}

\section{III. 台风风雨潮分析}

28 个影响渤海湾的台风中 50 年代 2 个, 60 年代 4 个, 70 年代 4 个, 80 年代 3 个, 90 年代 2 个, 2000 年
至 2010 年 5 个, 2011 年至 2018 年 8 个。可见 2000 年 以后进入渤海湾的逐渐增多, 尤其进入 2010 以后, 而且 影响强度增强。

3.1 台风一暴雨 
从秦皇岛西北陆地经过, 一般秦皇岛西北部降水大; 从海上进入关键区秦皇岛沿海降水大。由于秦皇岛地处 渤海沿岸, 小于 $100 \mathrm{~mm}$ 的降水很少造成灾害, 所以选取 大于 $100 \mathrm{~mm}$ 以上降水进行研究。造成秦皇岛大暴雨 (100mm) 以上量级降水的台风一共 7 次, 占总次数的 $25 \%$, 路径一般为图 1. a 箭头所示, 从西路再转向东北。 这也印证了台风的最大降水出现在右前方。有 1963.7.20 的 6307 号台风, 1978.7.26 的 7805 号台风、2002.7.28 的 0209 号台风, 2012.8.3-4 的 “达维” 台风, 2017.8.3 的 1710 号台风, 2018 的 “安比” 和 “摩羯” 台风。大 暴雨可以造成农作物被淹, 房屋毁坏, 还可能造成人员 伤亡。台风最大降水出现在 2012 年的 8 月 3-4 日的达维 台风影响, 最大降水量海阳镇 $308 \mathrm{~mm}$ 。这几次造成大降
雨的台风, 中心气压已经很弱, 风力也较小, 说明减弱 的台风仍然可以带来大量水汽, 造成大暴雨。

图 1.b 这是未造成秦皇岛暴雨的台风路径。没有进 入关键区。28 次台风中有 15 次未造成暴雨, 有两次不 足 10 毫米, 原因是距离秦皇岛太远。或者水汽通道不畅。 有 $1960.7 .28 、 1960.8 .5 、 1967.7 .29 、 1973.7 .19$ 、 1974. 8. 29、1992.9.1、2001.8.2、2005. 8.8、2008. 7.31、 2011.6.26、2011.8.8、2012.8.28、2018.8.19。还有出 现暴雨但不够大暴雨的个例, 1972.7.27、1978.7.26、 1985. 8. 19、1997.8.19、2004.9.15、2012.8.28, 共 6 次, 有 4 次伴有大风, 并且有灾情, 没有大风的暴雨灾 情较小。

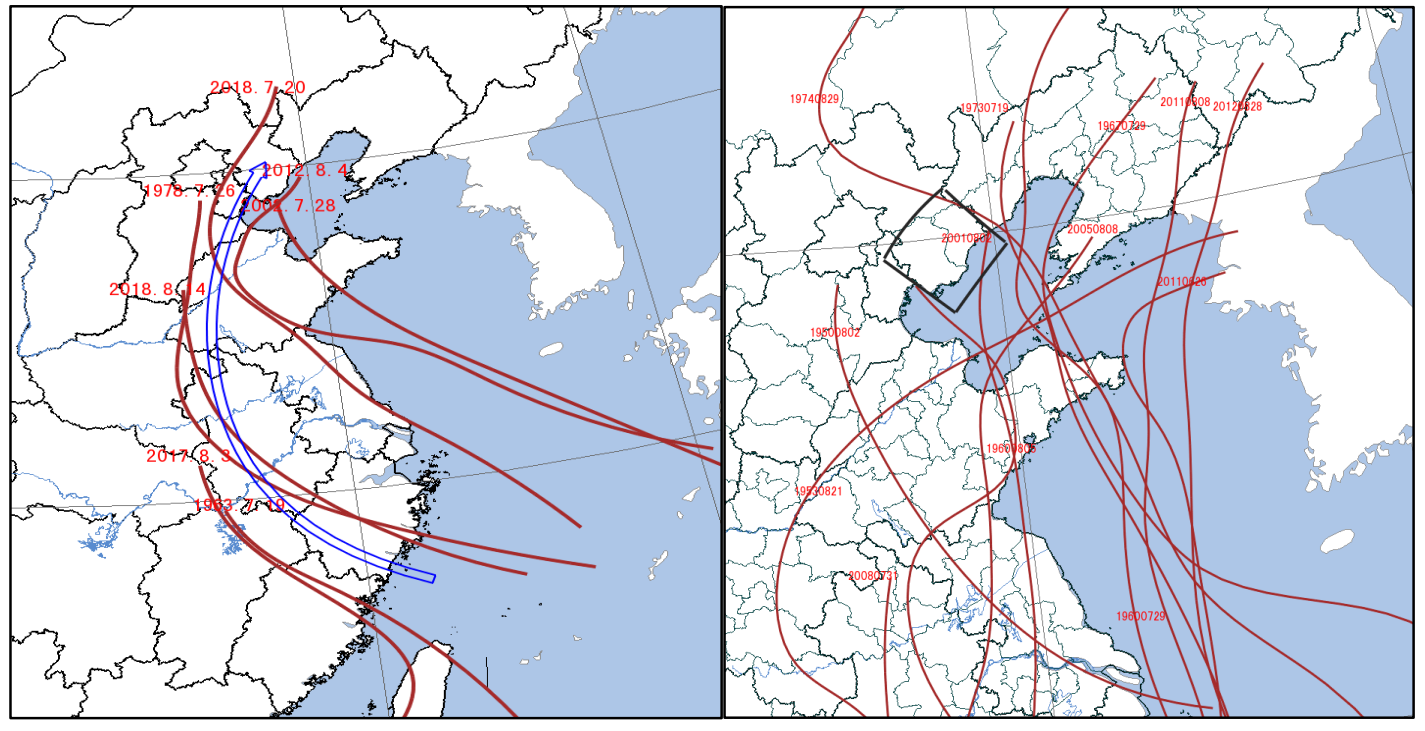

a 造成秦皇岛 $100 \mathrm{~mm}$ 以上大暴雨的台风路径

$\mathrm{b}$ 未造成暴雨的台风路径

图 1 台风降水分类图

\section{2 台风一大风}

台风造成的大风是最主要的灾害性天气。由于历史 记录原因, 我们选取日十分钟最大风速大于等于 $10 \mathrm{~m} / \mathrm{s}$ 或日极大风速大于等于 $17 \mathrm{~m} / \mathrm{s}$ 两个标准为一个大风日。 共有 11 次台风造成大风天气（有大风记录的台风共 22 次）, 占总次数的 $50 \%$ 。一般进入图 2 黑色关键区的台 风, 易造成秦皇岛大风天气, 大风以偏东风居多, 并且 有 6 次造成风暴潮。台风给秦皇岛造成大风的风向与中 心位置有关, 一般以东北风、东南风为主。风速大小与 台风中心与秦皇岛距离、中心风力成正比, 也与西来系 统有关, 使气压梯度加强, 风力加大。

\section{3 台风一风暴潮}

风暴潮, 主要造成河口地区海水倒灌, 淹没农田、 沿岸设施、建筑物等, 再加上大风大浪的作用, 破坏力 更大。

从 1949 年到 2018 年造成风暴潮灾害的台风共 7 次 (分别是 1949、1972、1985、1992、1997、2012、2017 年）, 都出现了大风。根据统计结果一般造成风暴潮灾 害的大风日平均最大风力超过 $10 \mathrm{~m} / \mathrm{s}$, 日极大风速超过 $17 \mathrm{~m} / \mathrm{s}$ 。并且都在农历的初四、初五, 十六、十七, 农 历初一、十五的天文大潮后 5 日内。还有几次潮位虽然 高, 但是无大风, 基本没有灾情。例如 2011 年 6 月 26 日, 2011 年 8 月 8 日, 潮位都超过 210 厘米, 无大风, 也没有灾情。 


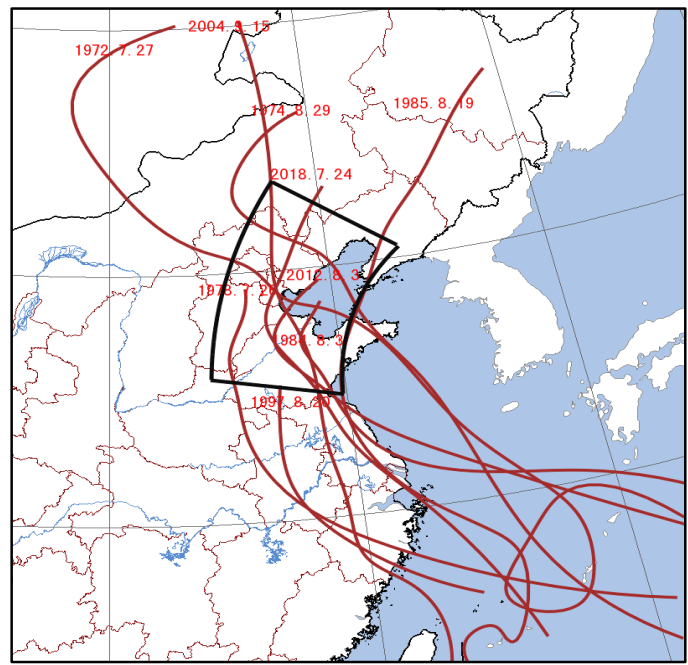

图 2 造成大风的台风路径图

\section{IV.台风灾情分类}

根据张国财《自然灾害风险评估原理和方法》台风 致灾因子风雨综合强度指数:

$$
x=\frac{R-25}{50} \quad y=\frac{f-13.6}{3.8}
$$

$(R$ 为降水量, $f$ 为极大风速。若 $R<25 \mathrm{~mm}, x$ 为 0 , 若 $\mathrm{f}<13.6 \mathrm{~m} / \mathrm{s}$, $\mathrm{y}$ 为 0 )

$$
I=\mathrm{Ax}+\mathrm{By}
$$

( $A 、 B$ 为风雨系数, 一般取 $A=0.6722, B=0.6639$ ) 根据上述公式将影响秦皇岛的台风分为三个等 级:

1 级 (强) 影响: 风雨综合强度指数 $\geqslant 1.0$ 或发生严 重风暴潮

2 级 (中等) 影响: 风雨综合强度指数 $\geqslant 0.6$ 或发生 较严重风暴潮

3 级（弱）影响: 风雨综合强度指数 $<0.6$

(上面所用的风速是极大风速, 十分钟平均最大风 速将 13.6 改为 $8 \mathrm{~m} / \mathrm{s}$ 。）

1 级（强）影响台风（ $I \geqslant 1.0 ）$ 灾情严重:

（1）1949 年 7 月 26 日，4906 号台风, 风暴潮, 无 气象风雨记录; 受其影响渤海海峡至北黄海风力 7-9 级, 渤海湾一带大潮侵入陆地 10 公里, 汉沽盐场被淹。

（2）1963 年 7 月 20 日，6307 号台风，秦皇岛 24 小时降雨量 $168 \mathrm{~mm}$, 大暴雨 ( $>100 \mathrm{~mm}$ ), 无大风记录, $\mathrm{I}>2$ 。

（3）1972 年 7 月 27 日，7206 号台风, 抚宁卢龙暴 雨, ENE 风, 风速 $21.3 \mathrm{~m} / \mathrm{s}$ 。台风纵穿黄海, 西行渤海,

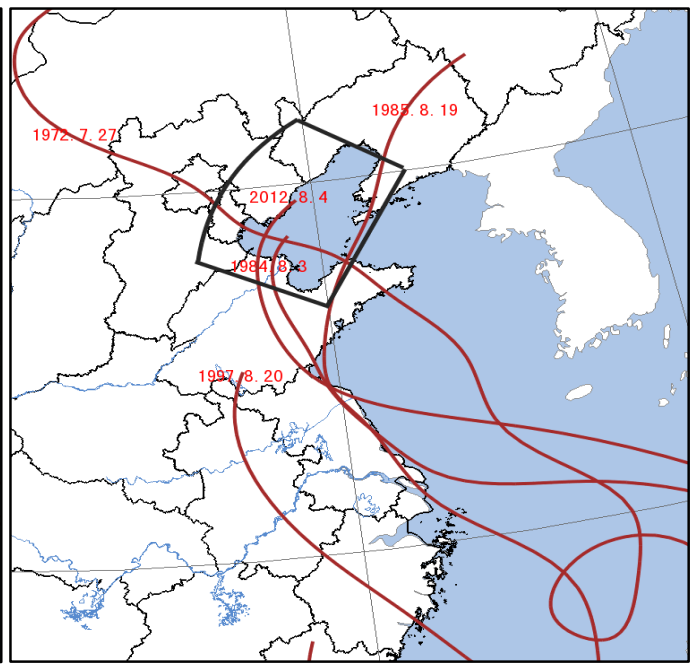

图 3 造成强风暴潮的台风路径

登陆塘沽。受其影响, 渤海地区出现 $9^{\sim} 11$ 级大风, 秦皇 岛最高水位为 $2.48 \mathrm{~m}$, 最大增水为 $1.83 \mathrm{~m}$; 秦皇岛 69 个 大队遭海水侵袭, 渔业损失较大, 海水内侵十多华里, 浸泡耕地严重。

（4）1978 年 7 月 26 日，7806 号台风，降雨量青龙 $150 \mathrm{~mm}$ 、卢龙 $67 \mathrm{~mm}$, 十分钟最大风速 $11.7 \mathrm{~m} / \mathrm{s}$, ESE 风。

（5）1985 年 8 月 19 日, 8509 号台风, 秦皇岛 $69 \mathrm{~mm}$, 昌黎十分钟最大风速 $11 \mathrm{~m} / \mathrm{s}$, NE 风。受其影响, 秦皇岛 最高水位为 $1.92 \mathrm{~m}$, 最大增水 $0.49 \mathrm{~m}$ 。昌黎毁船 4 艘、渔 网 500 多领, 冲毁虾池 30 亩, 损失虾苗 50 万尾, 山海 关养殖场贻贝损失严重。

（6）1992 年 9 月 2 日, 受 9216 号台风, 昌黎最大 降水 $18 \mathrm{~mm}$, 十分钟最大风速, $9.7 \mathrm{~m} / \mathrm{s}$, NE 风。河北沿海 水位暴涨, 秦皇岛最高水位为 $2.08 \mathrm{~m}$, 最大增水为 $0.87 \mathrm{~m}$ 。 秦皇岛岸段昌黎县㴒河口附近, 海水猛涨, 海滩变成一 片汪洋, 渔业损失严重, 收获的海哲被冲走, 4 条渔船 沉深入海底, 经济损失惨重。

（7）1997 年 8 月 20 日，9711 号台风, 昌黎降水量 $73 \mathrm{~mm}$, 十分钟最大风速, $14.0 \mathrm{~m} / \mathrm{s}$, ENE 风。秦皇岛最高 潮位为 $2.18 \mathrm{~m}$, 最大增水为 $0.71 \mathrm{~m}$, 秦皇岛岸段一些小型 旅游码头、海水养殖区防波堤受到不同程度破坏, 笼网 养殖扇贝全部损失, 很多渔船被毁, 直接经济损失 2 亿 元。

（8）2012 年 8 月 3-4 日，12 号台风 “达维” , 秦 皇岛降水量 $103 \mathrm{~mm}$, 昌黎极大风速 $17.0 \mathrm{~m} / \mathrm{s}$, NE 风。秦 皇岛最高潮位 2.13 米。昌黎境内出现严重的风灾和洪涝 灾害, 同时滦河上游水库放水泄洪, 㴒河堤坝多处出现 险情。全县 17 个乡镇（区） 418 个行政村全部受灾, 受 灾人口达 32 万人, 紧急转移安置人口 1.2 万人, 6 个乡 镇 82 个行政村受淹。全县农作物受灾面积 37.3 千公顷, 
成灾面积 33.6 千公顷, 绝收面积 12.2 千公顷, 造成农 业损失 3.9 亿元。全县因灾造成直接经济损失 5.6 亿元。 暴雨共造成海港区、山海关区和北戴河区 309142 人受 灾, 1 人死亡。倒塌房屋 2205 间, 一般损坏 52754 间。紧 急转移安置人口 74224 人, 农作物受灾面积 16134.36 公 顷, 绝收面积 8408.36 公顷。

（9）2017 年 08 月 03 日, 青龙最大降水量 $162 \mathrm{~mm}$, 秦皇岛极大风速 $17.9 \mathrm{~m} / \mathrm{s}$ 。全市受灾人口 10.23 万人次, 农作物受灾面积约 6947.6 公顷(其中昌黎县 4027 公顷, 卢龙县 412 公顷, 青龙县 747 公顷, 海港区 866. 7 公顷, 开发区 19 公顷，抚宁区 874.35 公顷），农作物绝收面 积 167.7 公顷（减产 8 成）。经过县区现场勘查, 倒塌 农房 12 间、严重损坏农房 49 间。此次灾害共造成直接 经济损失 5173.59 万元，无人员伤亡。

（10）2018 年 7 月 23 日-24 日, 受第十号台风 “安 比” 影响, 青龙降水量 $128 \mathrm{~mm}$, 卢龙极大风速 $21.5 \mathrm{~m} / \mathrm{s}$ 。 全市受灾人口 33.84 万人次, 累计农作物受灾面积约 2.96 万公顷,农作物成灾面积为 1.7 万公顷 (减少 3 成), 绝收面积 815 公顷（减产 8 成）。倒塌农房 1 户 4 间、 严重损坏农房 32 户 40 间。此次灾害共造成直接经济损 失 1.24 亿元，无人员伤亡。

（11）2018 年 8 月 14 日，受 1814 号台风 “摩羯” 影响, 秦皇岛降水量 $103 \mathrm{~mm}$, 昌黎极大风速 $17.0 \mathrm{~m} / \mathrm{s}, \mathrm{NE}$ 风。青龙县、昌黎县、卢龙县、山海关区、海港区相继 出现灾情, 受灾人口 93345 人次, 紧急转移安置人口 9 人。农作物受灾面积 8381.9 公顷, 农作物成灾面积 2492.39 公顷, 绝收 68. 36 公顷。倒塌房屋 10 户 18 间, 严重损坏房屋 43 户 87 间。累计造成直接经济损失 4948. 32 万元，无人员伤亡报告。基础设施损失主要包 括卢龙县 5 座桥梁损坏, 其中印庄乡一座, 燕河营镇 4 座; 印庄乡 8040 米乡间道路, 冲毁, 引青灌渠渠墙倒塌 200 米、倾斜 1550 米, 渠道淤积 16200 立方米; 山海关 区第一关镇村内桥冲毁 4 座, 海港区冲毁乡村公路 3350 米, 漫水桥 5 座。

2 级 (中等) 影响的台风, 基本没有大的灾情

（1）2002 年 7 月 28 日，0209 号台风，秦皇岛降水 量 $103 \mathrm{~mm}$, 十分钟最大风速, $6.3 \mathrm{~m} / \mathrm{s}$, E 风。 $\mathrm{I} \geqslant 1.0$

（2）2004 年 9 月 15 日，0420 号台风，卢龙降水量 $74 \mathrm{~mm}$, 秦皇岛极大风速, $17.3 \mathrm{~m} / \mathrm{s}, \mathrm{SE}$ 风。 I $\geqslant 1.0$

(3) 2011 年 6 月 26 日, 110 号台风米雷, 无风雨, 潮高 213 厘米

（4） 2011 年 8 月 8 日， 110 号台风梅花，无风雨, 高潮潮位 215 厘米

（5）2018 年 7 月 24 日， 1810 号台风 “安比”。
（6）2018 年 8 月 20 日，1820 号台风 “温比亚”, 潮高 201 厘米。

3 级（弱）影响台风, 无灾情

（1）1950 年 8 月 2 日，5010 号台风

（2）１953 年 8 月 21 日，5310 号台风

（3）1960 年 7 月 29 日，6005 号台风

（4）1960 年 8 月 5 日，6007 号台风

（5）1967 年 7 月 29 日，6709 号台风

（6）1973 年 7 月 19 日，7303 号台风

（7）1981 年 7 月 28 日，8109 号台风

（8）2005 年 8 月 8 日，0509 号台风 “麦莎”

（9）2008 年 7 月 31 日，0808 号台风。

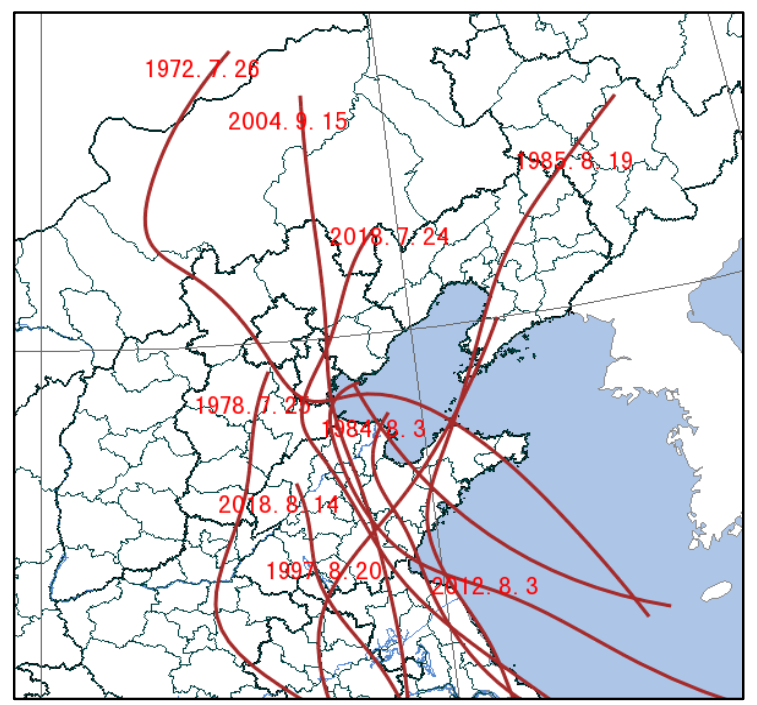

图 41 级强影响的台风路径

V. 风暴潮与地形、天文大潮的关系

风暴潮是发生在沿岸的一种海洋灾害。风暴潮能否 成灾, 要看当时是否遇上天文大潮的高潮, 如果高潮位 和大风两者叠加在一起, 成灾的可能性就很大。风暴潮 灾害的轻重, 除受风暴增水的大小和当地天文大潮高潮 位的制约外, 还要看受灾地区的地理位置、海岸形状、 海底地形、社会及经济情况。一般来说, 地理位置正处 于海上大风的正面袭击、海岸呈喇叭口形状、海底地势 平缓、人口密度大、经济发达的地区, 所受的风暴潮灾 害相对来讲要严重些。秦皇岛除河口地区, 喇叭口地形 不明显, 但地势比较平缓, 经济比较发达。属于中等程 度影响。

天文大潮主要受月球影响, 农历的初一十五为天文 大潮。从表 2 分析可以看出, 一般风暴潮出现在农历初 四到初五，或者十六到十八，天文大潮后两到五天。

\section{VI . 风暴潮的影响系统}

风暴潮灾害除地形外主要由大风和高潮水位共同引 起的。造成秦皇岛风暴潮的天气系统主要有三种: 台风、 温带气旋、强冷空气。由于秦皇岛海岸线呈东北西南向, 
所以东南风容易使潮位上涨，西北风使潮位下降。

\section{1 台风一风暴潮}

前面已经讨论过，不再赘述。例如：1972、1985、 1992、1997、2012 年 8 月 3-4 日。

\section{2 温带气旋一风暴潮}

受江淮气旋或黄河气旋影响, 秦皇岛地面吹偏南大 风, 尤其江淮气旋以东南风为主, 与秦皇岛海岸线垂直, 最有利于风暴涨水。

例如：2013年5月27日，2016年7月20日。这两次都 超过了 218 厘米的黄色警戒水位, 是 2000 年以来的最高水 位。2016年7月20日受江淮气旋影响, 全市共造成直接经 济损失 26.15 亿元, 其中: 农业损失 7.47 亿元; 工矿企业
损失 254.2 万元, 基础设施类损失 16.25 亿元; 公益设施 类损失 7146 万元, 家庭经济损失 1.69 亿元。其他损失 8.68 亿元 (包括一是岸滩及旅游设施损失 5.58 亿元, 二是海 产养殖损失、27条公务执法船、92条渔船沉没, 造成经 济损失 3.1 亿元）。合计损失 34.82 亿元。

\section{3 强冷空气一风暴潮}

强冷空气是造成风暴潮的又一类天气形势，一般发 生在冬半年, 它可以给秦皇岛沿岸造成持续的偏东或东 北大风, 大风有东南分量时可使潮水上涨, 潮位升高。 1964 年 4 月 5-6 日, 受冷峰配合低压的影响, 渤海东北 风 $20 \mathrm{~m} / \mathrm{s}$, 河北沿海水位暴涨。北戴河刘庄六座楼房花 园水深齐腰, 海浪淘空外交部休养所路基 3 处, 中海滩 南花园被淹, 昌黎、抚宁海潮上涨, 农田积水。

表 2 1972-2018 年风暴潮风雨潮

\begin{tabular}{|c|c|c|c|c|c|c|c|c|c|}
\hline 观测时间 & 农历 & 灾情 & $\begin{array}{l}\text { 天气 } \\
\text { 系统 }\end{array}$ & $\begin{array}{l}20-20 \\
\text { 降水量 }\end{array}$ & $\begin{array}{l}\text { 日最 } \\
\text { 大风 } \\
\text { 风速 }\end{array}$ & $\begin{array}{l}\text { 日最 } \\
\text { 大风 } \\
\text { 风向 } \\
\end{array}$ & $\begin{array}{l}\text { 日极 } \\
\text { 大风 } \\
\text { 风速 }\end{array}$ & $\begin{array}{l}\text { 日极 } \\
\text { 大风 } \\
\text { 风向 }\end{array}$ & $\begin{array}{l}\text { 最高潮 } \\
\text { 位 }(\mathrm{cm}) \\
\end{array}$ \\
\hline $1972 / 7 / 27$ & 6.16 & 大灾 & 7203 台风 & 61.3 & 21.3 & ENE & & & 248 \\
\hline 1985/8/19 & 7.4 & 中灾 & 8509 台风 & 69.2 & 11 & NNE & & & 192 \\
\hline 1992/9/1 & 9.1 & 大灾 & 9216 台风 & 18 & 9.7 & $\mathrm{NE}$ & & & 208 \\
\hline $1997 / 8 / 20$ & 7.18 & 大灾 & 9711 号台风 & 73 & 14 & ENE & & & 218 \\
\hline 2003/10/11 & 9.16 & 大灾 & 冷空气 & 83.6 & 15.3 & ENE & & & \\
\hline 2008/5/10 & 4.6 & 无灾 & 黄河气旋 & 0 & 8.1 & SSW & 11.8 & ENE & 204 \\
\hline $2008 / 7 / 1$ & 5.28 & 无灾 & 蒙古气旋 & 16.5 & 5 & ESE & 7.5 & ESE & 201 \\
\hline $2008 / 7 / 5$ & 6.3 & 小灾 & 黄河气旋 & 58.1 & 9 & NNE & 9.3 & $\mathrm{SE}$ & 214 \\
\hline $2008 / 7 / 30$ & 6.28 & 无灾 & 0808 号“凤 & 0 & 4.3 & $\mathrm{SE}$ & 5.9 & ESE & 201 \\
\hline $2008 / 7 / 31$ & & 无灾 & 凰” 北上外围 & 14 & 4.9 & SE & 7.9 & SSE & 209 \\
\hline $2008 / 8 / 27$ & 7. 10 & 无灾 & 冷空气 & 0.7 & 3.1 & SSW & 5.3 & SE & 201 \\
\hline $2009 / 6 / 24$ & 5.2 & 无灾 & 蒙古气旋 & 0 & 6.5 & S & 9.9 & WSW & 206 \\
\hline $2010 / 12 / 5$ & 10. 30 & 无灾 & 冷空气 & 0 & 6.5 & NNE & 11.3 & NNE & 201 \\
\hline $2011 / 6 / 26$ & 5.25 & 小灾 & $\begin{array}{l}1105 \text { 号 “米雷” } \\
\text { 北上 }\end{array}$ & 0.2 & 8.2 & $\mathrm{NE}$ & 11.8 & ENE & 213 \\
\hline $2011 / 8 / 7$ & 7.8 & & 1109 号 “梅 & 8.4 & 4. 6 & E & 6.7 & $\mathrm{E}$ & 200 \\
\hline $2011 / 8 / 8$ & & 小灾 & 花”北上 & 3.1 & 4. 6 & W & 6.6 & SW & 215 \\
\hline $2012 / 8 / 3$ & 6.16 & 大灾 & 1210 号 “达 & 51.2 & 7.4 & ENE & 10.6 & $\mathrm{E}$ & 213 \\
\hline 2012/8/4 & 6.17 & & 维”北上 & 183.8 & 11.6 & $\mathrm{NE}$ & 17 & $\mathrm{NE}$ & \\
\hline $2012 / 8 / 27$ & 7.11 & 无灾 & $\begin{array}{l}1215 \text { 号 “布拉 } \\
\text { 万” 北上 }\end{array}$ & 50.5 & 3.9 & ENE & 5.8 & ENE & \\
\hline $2012 / 8 / 28$ & 7. 12 & 无灾 & & 0 & 3.7 & WNW & 5.4 & WNW & 202 \\
\hline $2013 / 5 / 27$ & 4. 18 & 小灾 & 江淮气旋 & 2.6 & 5.7 & E & 8.2 & ESE & 224 \\
\hline $2016 / 7 / 20$ & 6.17 & 大灾 & 江淮气旋 & 182.8 & 9.5 & E & 16.5 & ESE & 227 \\
\hline $2016 / 8 / 27$ & 7.25 & 无灾 & 冷空气 & 18. 2 & 9.2 & $\mathrm{~N}$ & 15.5 & $\mathrm{~N}$ & 201 \\
\hline 2016/10/24 & 9.24 & 无灾 & 江淮气旋 & 0 & 3.3 & SE & 5.3 & SE & 200 \\
\hline 2017.8. 3 & 6.12 & 中灾 & “海棠” 北上 & 162.3 & 9.8 & SSE & 17.9 & SE & 202 \\
\hline $2017 / 9 / 16$ & 7.25 & 无灾 & 蒙古气旋 & 0 & 3.1 & SSW & 6.9 & SW & 200 \\
\hline $2018 / 8 / 20$ & 7.8 & 小灾 & “温比亚” 北上 & 38.3 & 8.3 & $\mathrm{NE}$ & 14.8 & $\mathrm{NE}$ & 201 \\
\hline
\end{tabular}




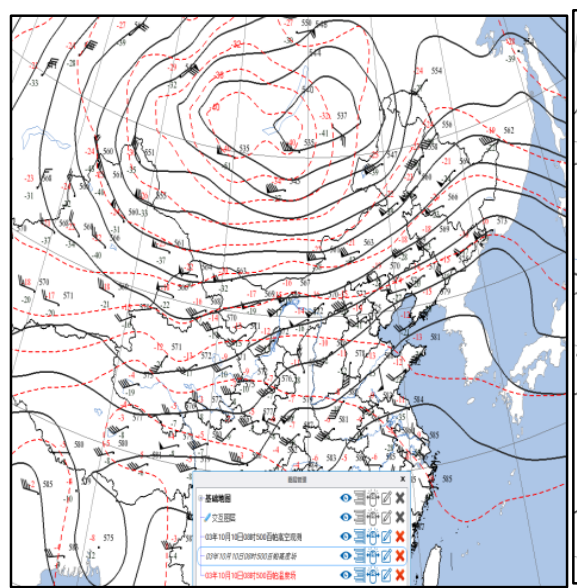

a 强冷空气影响

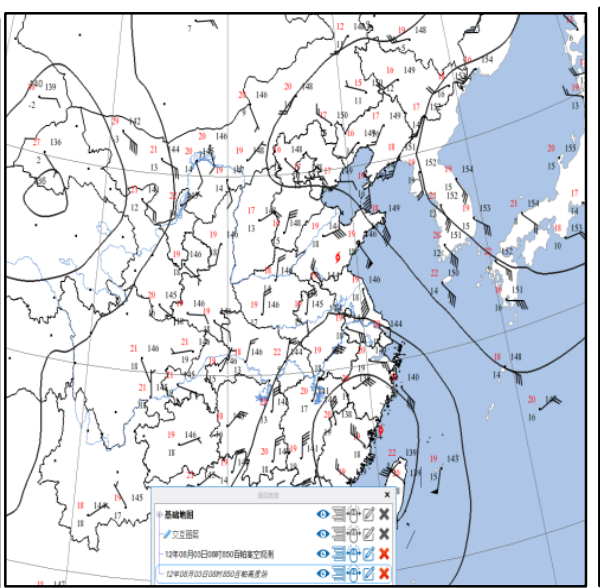

b 台风影响

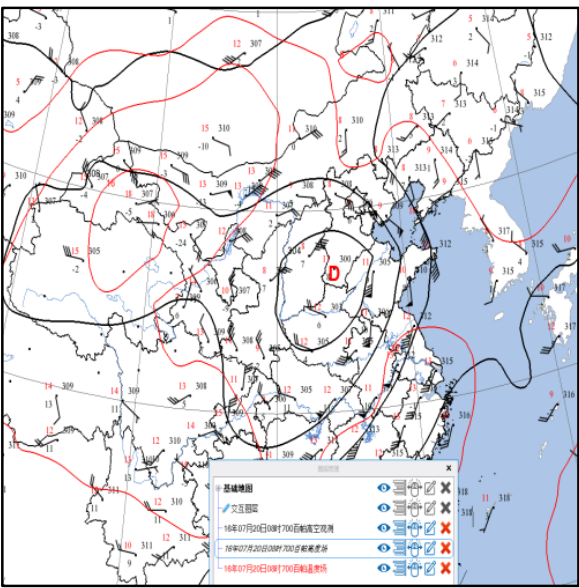

c 温带气旋影响

图 5 风暴潮的三种天气形势

如果强冷空气造成地面西北大风或偏北大风, 而有 负东南分量时, 可能会造成风暴减水。2003 年 10月 11-12 日受北方强冷空气影响, 渤海沿岸发生了一次强温带风 暴潮。(秦皇岛本次过程是一个减水过程, 因此主要是 大浪造成的灾害; 唐山和沧州地区主要是风暴潮灾害) 秦皇岛市沿海出现 2.7-3.2 米大浪, 在大浪的作用下昌 黎、抚宁沿海受到不同程度损害, 特别是 4 海里以外养 殖区的养殖台筏挤成堆纠缠在一起, 扇贝养殖区 27 万亩, 约 900 万笼全部损失; 70 艘渔船损坏; 直接经济损失约 2.0 亿元。

总之造成风暴潮的重要因素就是大风, 引发风暴潮 的大风一般超过 $10 \mathrm{~m} / \mathrm{s}$, 与海岸线垂直, 正负 $90^{\circ}$ 角, 即 秦皇岛在东北风与西南风之间, 但西南风很少发生风暴 潮, 一般在东北风到偏南风之间, 最多的是东南风。所 以造成秦皇岛风暴潮的主要天气系统是台风和江淮气旋。 北方强冷空气是造成秦皇岛风暴潮的次要天气系统, 因 为北方强冷空气一般以偏北风为主, 很少有东南风向分 量。秦皇岛北戴河南天门为一突出半岛, 东北风可以使 其受灾。

\section{VII. 小结}

通过对 1949-2018 年进入渤海湾影响秦皇岛的 28 个 台风进行分析, 造成秦皇岛 $100 \mathrm{~mm}$ 以上大暴雨一共 7 次, 占 $25 \%$; 11 次大风天气, 占 $50 \%$ （共 22 次）；风暴潮 6 次, 占 $21 \%$ （共 28 次）。一般只有降水, 没有大风和风 暴潮发生, 要超过 $100 \mathrm{~mm}$, 才会有灾情。如果有大风, 一般大于 $50 \mathrm{~mm}$ 降水就会发生灾情; 如果有大风再有风暴 潮, 那么灾害就会更大。

根据风雨强度公式, 再根据秦皇岛地区的实际情况, 将表 1 中台风进行分类, 按照台风的综合强度分为三类: 第一类强影响台风: 造成大风强降水或大的风暴潮, 可
以造成严重的自然灾害, 比如农作物倒伏、被淹, 建筑 物、设施倒塌, 人员伤亡, 海上船只遇险, 海岸带被淹 等。第二类中等影响台风: 较大降水 (50-100mm), 较 强大风 (十分钟最大风速在 $8-10 \mathrm{~m} / \mathrm{s}$ 之间, 极大风速在 $13.6-17 \mathrm{~m} / \mathrm{s}$ 之间), 或超过警戒水位但没有大风的高潮 位。可能会造成比较严重的灾情, 但不太严重。第三类 弱影响台风: 无灾情。

造成风暴潮的主要天气系统有台风、温带气旋、强 冷空气。这些天气产生向岸的有东南分量的大风是造成 秦皇岛风暴潮的主要因素, 潮位与风速成正比, 大风如 果赶上天文大潮就会产生风暴潮。如果只有潮位上涨, 没有大风, 一般没有太大的灾害。大的风暴潮灾害一般 四五年一次, 但是 2010 年以后风暴潮灾害有所增加。

\section{参考文献}

[1] 王月宾. 渤海西岸风暴潮预报方法研究[J]. 《兰州大学学报》

[2] 张国财. 《自然灾害方向为评估与区划原理和方法》 [M]. 气象出版社

[3] 牛海燕.中国沿海台风灾害风险评估研究[J]. 《华东师范大学》

[4] 王秀荣.台风灾害综合等级评估模型及应用[J].《气象》

[5] 卢美浙.江海岸台风风暴潮漫堤风险评估研究[D]. 浙江大学 2014

[6] 郑立松. 风暴潮一天文潮一波浪耦合模型及其在杭州湾的应用 [D]. 清华大学. 2010

[7] 黄静.沿海重要港口风暴潮灾害危险性研究[D]. 华东师范大学 2012 [8] 陈连友.秦皇岛沿海灾害性天气对自然环境的影响和预报[J].中国环 境管理干部学院学报 